\title{
Every Night.
}

National Cancer Institute

\section{Source}

National Cancer Institute. Every Night.. NCI Thesaurus. Code C139178.

Occurring or done each night. 